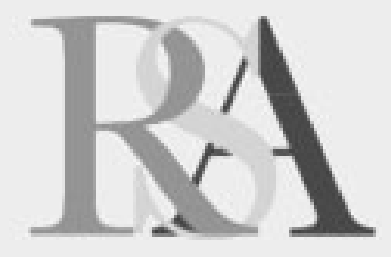

Gender and Politics in the Henrician Court: The Douglas-Howard Lyrics in the Devonshire Manuscript (BL Add 17492)

Author(s): Bradley J. Irish

Source: Renaissance Quarterly, Vol. 64, No. 1 (Spring 2011), pp. 79-114

Published by: The University of Chicago Press on behalf of the Renaissance Society of America

Stable URL: http://www.jstor.org/stable/10.1086/660369

Accessed: 07/04/2011 22:55

Your use of the JSTOR archive indicates your acceptance of JSTOR's Terms and Conditions of Use, available at http://www.jstor.org/page/info/about/policies/terms.jsp. JSTOR's Terms and Conditions of Use provides, in part, that unless you have obtained prior permission, you may not download an entire issue of a journal or multiple copies of articles, and you may use content in the JSTOR archive only for your personal, non-commercial use.

Please contact the publisher regarding any further use of this work. Publisher contact information may be obtained at http://www.jstor.org/action/showPublisher?publisherCode=ucpress.

Each copy of any part of a JSTOR transmission must contain the same copyright notice that appears on the screen or printed page of such transmission.

JSTOR is a not-for-profit service that helps scholars, researchers, and students discover, use, and build upon a wide range of content in a trusted digital archive. We use information technology and tools to increase productivity and facilitate new forms of scholarship. For more information about JSTOR, please contact support@jstor.org.

The University of Chicago Press and Renaissance Society of America are collaborating with JSTOR to digitize, preserve and extend access to Renaissance Quarterly. 


\title{
Gender and Politics in the Henrician Court: The Douglas-Howard Lyrics in the Devonshire Manuscript (BL Add 17492)*
}

\author{
by BRADLEY J. IRISH
}

\begin{abstract}
BL Additional MS 17492, the so-called Devonshire Manuscript of Henrician courtly verse, is a prime example of how social and cultural phenomena contributed to early modern manuscript culture. Among the treasures of the Devonshire MS is a series of lyrics that chronicles a fascinating courtly intrigue of the 1530s: the illicit, clandestine marriage of Lord Thomas Howard and Lady Margaret Douglas, the headstrong niece of Henry VIII. After unpacking this historical drama, this essay advances the first substantial literary analysis of these poems by exploring the textual strategies through which Howard and Douglas attempted to negotiate the crown's insistent management of their erotic life. This treatment of the Douglas-Howard lyrics provides new opportunity to consider how the Devonshire MS reflects and refracts the gender dynamics of the contemporary Henrician court.
\end{abstract}

\section{INTRODUCTION}

I n the playful fable "Eache beeste can chuse his feere," Henry Howard, the famed poet and Earl of Surrey (ca. 1517-47), recounts the failed seduction of a rival's lady. ${ }^{1}$ In the midst of his flirtation, Surrey invokes a remarkable anecdote from his family's recent history, as a pledge of his own honesty in love:

And, for my vaunte, I dare well say my blood is not untrew;

Ffor you your self dothe know, it is not long agoe,

Sins that, for love, one of the race did end his life in woe

In towre both strong and highe, for his assured truthe. ${ }^{2}$

"This project originated in the Mellon Summer Institute for Vernacular Paleography hosted by the Folger Shakespeare Library in July 2009; I thank Heather Wolfe, Owen Williams, Steven W. May, Alan Stewart, and Adrienne Shevchuk for their guidance and support during the seminar. I am also greatly indebted to Jason Powell, Raymond G. Siemens, Marjorie Curry Woods, Frank Whigham, Wayne A. Rebhorn, Noël Clare Radley, Ruth Ahnert, Kristen P. Walton, and my colleagues at the University of Texas at Austin. I am especially grateful to the editors, reviewers, and staff of Renaissance Quarterly, whose kind and generous attention has strengthened the essay tremendously.

${ }^{1}$ Within the framework of a beast fable, this poem describes how a lion (the emblematically appropriate stand-in for Surrey) is refused in his courtly advances by a coy wolf, a figure long said to represent Lady Anne Stanhope, the wife of Surrey's rival Edward Seymour.

${ }^{2}$ Surrey, 74 ("Eache beeste can chuse his feere according to his minde," 11. 34-37). 
These lines almost certainly allude to the fate of Surrey's young uncle, Lord Thomas Howard, who in July of 1536 was condemned to the Tower "for making a privie contracte of matrimonie betweene the Ladie Margarett Duglas and him, which ladie is daughter to the Queene of Scottes ... and neece to the Kinge." ${ }^{3}$ Though seemingly legal at the time, Howard's betrothal to a royal niece entered him squarely into the realm of dynastic politics, and the cost of this intrusion was heavy. By meddling such with royalty, Howard presented a clear threat to the crown's dynastic agenda, and King Henry VIII (1491-1547), unsurprisingly, was not inclined to tolerate such encroachment on the royal prerogative. In the ensuing events Howard would lose his life, and England's treason statutes would further swell to include in their purview any such dalliance not sanctioned by the king.

Although the life and death of Thomas Howard is but a minor episode in Henry's long, turbulent reign, the social drama of Lord Thomas and Lady Margaret is of no small interest to the literary history of the early sixteenth century: both parties have unmistakable ties to British Library Additional MS 17492 (the so-called Devonshire Manuscript), arguably the most important extant manuscript witness to the social circulation of early Tudor courtly verse. Associated mainly with the household of Queen Anne Boleyn in the 1530s, the Devonshire MS contains almost 200 poems, inscribed by some twenty different hands. Though long valued as a source of Sir Thomas Wyatt's verse, the manuscript has become increasingly recognized as a prime example of how social phenomena contributed to early modern manuscript culture and how, more specifically, men and (especially) women at court negotiated the relationship between poetry, politics, and power. ${ }^{4}$ As we will see, both Howard and Douglas figure notably throughout, appearing in various forms as copyists, annotators, and composers of original verse. Many of these original lyrics seem to refer explicitly to the facts of their scandal, and there is even evidence to suggest that certain poems emerged from the time of their imprisonment.

Scholars of the Devonshire MS have often recognized that the DouglasHoward scandal is a contextual backdrop for portions of the manuscript. ${ }^{5}$ Yet for many reasons - including that the manuscript has never been edited literary scholarship on the lyrics has tended toward the casual, the descriptive,

${ }^{3}$ Wriothesley, 1:54.

${ }^{4}$ Marotti, 40, notes that the traditional, Wyatt-centered approach largely "distorts" the character of the manuscript, by effacing its social context. On the social practices of manuscript circulation more generally, see ibid.; Boffey; North.

${ }^{5}$ The biographical context of the lyrics was first noted by Bond. 
and the incomplete. ${ }^{6}$ While there exists fine work on discrete aspects of the poems - such as Elizabeth Heale's investigation of women's participation in the Devonshire, and Seth Lerer's work on the medieval context of Henrician poetry - there has been no attempt to offer a complete reading of Lord Thomas and Lady Margaret's presence in the manuscript. ${ }^{7}$

It is the goal of this article to correct this deficit, by offering an inclusive account of how Lord Thomas Howard and Lady Margaret Douglas, and the scandal of their clandestine marriage, contributed to the shape of the Devonshire MS. To this end, the essay is divided into two parts of unequal length. First, the historical narrative of the Douglas-Howard scandal will be unpacked, to enable a contextually sensitive discussion of the poems with which it is associated. More importantly, a substantial literary account of the lyrics will then be advanced, in order to map both their contextual and their poetic features. Encompassing the majority of the discussion, this approach will subject the poems themselves to more rigorous analysis than has been offered in previous treatments. Consistent with recent scholarly approaches, this dual consideration will ultimately provide new opportunity to explore how the Devonshire MS reflects and refracts the gender dynamics of the contemporary Henrician court by elucidating how both Margaret Douglas and Thomas Howard attempted to negotiate the crown's insistent management of their erotic life.

\section{The Life and Times of Lord Thomas Howard AND LADY MARGARET DOUGLAS}

In a dispatch of 23 July 1536, Eustace Chapuys, the imperial ambassador to England, sent word of recent events in King Henry's court: “They have condemned to death . . . the younger brother of the duke of Norfolk for having tested a marriage parparolles de present with the daughter of the queen of Scots and Earl of Angus. A statute has also been passed making it treason to treat for marriage with anyone of the blood royal without the King's consent. The said personage of the blood royal was also to die, but for the present has been pardoned her life considering that copulation had not taken place; and certainly if she had done much worse she deserved pardon, seeing the number of domestic examples she has seen and sees daily, and that she

${ }^{6}$ Raymond G. Siemens and his colleagues at the University of Victoria are currently preparing an edition of the manuscript. Some of the lyrics are transcribed, however unreliably, in Muir.

${ }^{7}$ See Heale, 1995; Lerer. Other work on the manuscript includes Seaton; Harrier; Southall, 1964 and 1994; Baron; Siemens et al. 
has been for eight years of age and capacity to marry. Since the case has been discovered she has not been seen, and no one knows whether she be in the Tower, or some other prison." 8 This, in digest form, records the series of wild events that for several months in 1536 befell Lord Thomas Howard and Lady Margaret Douglas, two prominent members of England's aristocratic elite. Their story bears consideration in some detail.

Little is known about the early years of Lord Thomas Howard (ca. 1512-37), the youngest surviving son of Thomas Howard, Earl of Surrey the great patriarch of the Henrician Howards, whose success at Flodden Field in 1513 recovered for his family the Dukedom of Norfolk — and his second wife, Agnes Tilney. Lord Thomas was thus born on the edge of Henrician England's most formidable aristocratic dynasty: by the mid1530s, his family included the realm's senior peer (half-brother), its queen (niece), its earl marshal (brother), its most promising young poet-statesman (nephew), and its future queen (niece). He seems to have first arrived at court in 1533, when the Boleyn marriage occasioned an influx of the new queen's Howard kin. ${ }^{9}$ Needless to say, Lord Thomas was well connected.

Daughter of the Earl of Angus and Margaret Tudor, and thus niece to Henry VIII, Lady Margaret Douglas (1515-78) was a figure of even greater prominence. Though raised primarily in Scotland, which was then ruled by her half brother James V, Margaret possessed a solid claim to the English throne - and as such she was of enormous value to Henry, both at home and (as marriage fodder) abroad..$^{10}$ Because of this pedigree, Margaret was kept close to the English royal family; she spent the first years of her life under the protection of King Henry, and she returned to the English court in 1530, fleeing the volatile clan warfare that ravaged Scotland. She joined Queen Anne's household in 1533, where she became enmeshed in a courtly network of Howard ladies and their associates, becoming close to Mary Howard - sister to Surrey and eventual wife to the king's illegitimate son, the Duke of Richmond - and to Mary Shelton, cousin to Queen Anne and a formidable courtly presence.

${ }^{8}$ Letters and Papers, Foreign and Domestic, of the Reign of Henry VIII, 11:147. (Hereafter $L \& P$ : references are to document numbers.)

${ }^{9}$ For biographical data on both Howard and Douglas, see Marshall; Riordan. The only modern study of Thomas Howard, to which this article is heavily indebted, is Head.

${ }^{10}$ In a dispatch of March 1534, the French ambassador Castillon reports that King Henry has "a niece, daughter of the queen of Scotland, whom he keeps with the Queen his wife, and treats like a queen's daughter, and if any proposition were made for her, he would make her marriage worth as much as his daughter Mary's. I assure you the lady is beautiful, and highly esteemed here": L\&P, 7:13. 
Over the next two years, Margaret rose to great favor in the court of Queen Anne, and it was in 1535 that she first met, and apparently soon came to love, Thomas Howard. ${ }^{11}$ According to depositions made at the time of Howard's arrest, the pair conducted their secret affair at Anne's court: in one interview, the household servant Thomas Smyth reports having seen the lovers consort "diuerse tymes in somoche that [Lord Thomas] wold watche tyl my lady bulleyn was goon and thenne stele in to her chambre." 22 The romance blossomed in the spring of 1536, and in that April the pair married covertly per verba de presenti. Though Lord Thomas claimed that only two were party to the solemnization - Lady Williams and one Hastings, a servant of his mother - it is hard to be certain who was aware of the marriage. ${ }^{13}$ The matter was kept hidden for several months, as the lovers faced no disfavor throughout the early summer: in June 1536, Margaret participated in a ceremonial procession for Henry and his new queen, Jane Seymour, while in early July, King Henry attended a wedding of Howard associates at which Lord Thomas was likely present. ${ }^{14}$ Within only days, however, the affair came to the king's attention, and the courtly romance imploded.

Margaret and Thomas did not choose a good time to fall in love. After miscarrying in January 1536, Anne Boleyn's position had steadily declined, and by April, her tragic fate was all but sealed: in the span of only two months, Anne fell, Jane Seymour rose, and Parliament was left to untangle another muddled succession. The succession act of 4 July, aimed at blotting the stain of the traitress Anne, left King Henry in a troublesome bind: because of her mother's disgrace, the young Elizabeth joined her siblings Mary and Henry Fitzroy in bastardy, and the king was left suddenly without legitimate issue. ${ }^{15}$ By virtue of her royal blood, Margaret was catapulted to a position of enormous political importance: as King Henry was well aware, a Tudor daughter of spotless credentials could play a crucial role in the

\footnotetext{
${ }^{11}$ At the time of his deposition, on 8 July, Lord Thomas claimed that he had loved Margaret for "aboute a twelue moneth": see London, National Archives (hereafter NA), E $36 / 120$, fol. $55^{\mathrm{r}}$. This essay aims for semidiplomatic transcription. Expanded abbreviations from the manuscript are supplied in italics; clarifying notes, when necessary, are indicated by brackets.

${ }^{12} \mathrm{Ibid}$., fol. $53^{\mathrm{v}}$. Yet the relationship seems to have been an open secret in the Boleyn and Howard circle, and the queen may well have been aware of the affair; Smyth and the unidentified John Ashley, for example, both claim that they had "penceyved love betwene them" for at least "a quartr of a yere": ibid., fol. $53^{\mathrm{r}}$.

${ }^{13}$ Ibid., fol. $55^{\mathrm{r}}$.

${ }^{14}$ Head, 8; Wriothesley, 1:48, 50 .

${ }^{15}$ Henry Fitzroy, Duke of Richmond (1519-36), was King Henry's bastard son by Elizabeth "Bessie" Blount. On the details of his short life, see Murphy.
} 
future of his family's dynasty. The Duke of Richmond's sudden death only weeks after the scandal broke made matters worse. ${ }^{16}$ With Richmond gone, Margaret was an even greater potential asset to the king, and her unauthorized marriage was thus of even greater consequence.

After the revelation of their marriage in early July 1536, both Douglas and Howard were arrested immediately. On 9 July members of the Boleyn household were interrogated, and at the same time Howard himself admitted to the nature of his relationship with Margaret. Within a week, this alleged infraction was deemed worthy enough to warrant legislative leverage: on 18 July, the bill of attainder against Howard was introduced into Parliament and was passed on the same day. ${ }^{17}$ Having secured statutory insurance against infractions of a similar nature, King Henry was free to retain his prisoners in the Tower, to deal with at his pleasure. On 12 August, the Scottish Queen Margaret wrote to Henry to protest her daughter's treatment; she expressed shock at Henry's displeasure, and begged her brother "to grant our sad dochtyr Margaret Zour Grace pardon grace and fawour." ${ }^{\text {"18 }}$ By the end of the year, Henry appears to have softened some, at least toward his niece: in November she was transferred from the Tower to house arrest at Syon Abbey, and in late December Henry promised his sister that Lady Margaret would henceforth be treated well, provided she remain "convenient."19

Yet the Douglas-Howard scandal retained a measure of public interest well into the new year: for example, Sir Francis Bigod, a rebel associated with

${ }^{16}$ Despite his bastardy, Richmond had been groomed by his father as potential heir to the crown; in July 1536, Chapuys noted that Henry had "certainly intended to make [Richmond] successor, and but for his illness, would have got him declared so by parliament": L\&P, 11:147. For a brief period in mid-1536, all three of Henry's living children were illegitimate - Richmond by nature, and Mary and Elizabeth by statute and, for obvious reasons, in these circumstances Henry much preferred the prospect of leaving the crown to a son. For this reason, Richmond's death only made Margaret a more attractive candidate, as a legitimate niece could perhaps trump two illegitimate daughters.

${ }^{17}$ Journal of the House of Lords, 101.

${ }^{18}$ State Papers, Henry VIII, 5:58.

${ }^{19}$ On 6 November, the Abbess of Syon wrote to Cromwell: "as towchyng the ladye Margaret Douglace: I schalbe redye and glad to receyve her to sutche lodgyng walkes and commodyetyes, as be or maye be to her comfort and our princes pleasure, in our precyncte. And what service and pleasure schalbe in us to do vnto her, we schalbe ever redye to do, att the wyll of our sayd gracyous lord, to be opend vnto us by your lordschyppys certyfyeate": NA, SP $1 / 110$, fol. $186^{\mathrm{r}}$. As a still-valuable royal heir, Lady Margaret's confinement at the abbey was much more comfortable than her paramour's stay in the Tower: in December 1536, a parcel containing such fineries as "depe crymsen sylke," "frynge of silver," and "crymson vellet" was delivered to her chamber: NA, SP 1/113, fol. $49^{\mathrm{r}}$. For Henry to Margaret, see L\&P, 11:1373. 
the Pilgrimage of Grace, reported as late as February 1537 the rumor that the Howard attainder was orchestrated "bycawse the lorde cromwell shuld haue had the ladye margrete hyme selfe." ${ }^{20}$ The situation seems to have been largely unchanged until October, when a pair of events introduced a shift in political fortunes: on 12 October, Jane Seymour delivered Henry a baby boy - thus settling the vexed succession issue - and on 31 October, Lord Thomas succumbed to illness in the Tower. ${ }^{21}$ In light of these events, Henry felt secure enough to pardon the Lady Margaret, who was soon "sett agayne at her libertie" - though she indeed took her lover's death "very heavilie." ${ }^{\prime 2}$ To conclude the unhappy affair, Margaret was finally ordered to dismiss from her household two former servants of her lover, for it was the crown's "plesuer that [she] shall kepe non that ded be long vnto my Lord Thomas." 23

The Douglas-Howard scandal, such as it was, seems to have been relatively shortlived; soon all was well for Lady Margaret, whose (scandalous) life in Tudor politics would extend well into the reign of Elizabeth. Yet the fallout of these few tense months would indeed leave a stamp on the nation's statutes, enabling King Henry to exert an even firmer grasp on exactly what did and did not constitute treason in his realm. In fact, the attainder of Lord Thomas was one of only three occasions in Henry's reign that a parliamentary statute convicted an individual of treason as it simultaneously generalized the crime as treason in the future: that is, Howard was sentenced for an action that was only criminalized via retroactive, post facto legislation, and he was convicted under a statute that only came into existence by means of that very

${ }^{20} \mathrm{NA}$, SP 1/116, fol. 163: "of the lorde thomas and laydie margrete and the [statute] concernyng the same: the hole communicacion of all (so oft as occasion was goven to talke of the saide lords attayndre) was that bycawse the lorde cromwell shuld haue had the ladye margrete hyme selfe he procured the statute therfore." According to Bigod in another deposition, the Pilgrims ruled that Cromwell could be condemned of heresy for his role in the Douglas affair, and for his royal pretension: L\&P, 12:532. For Bigod, see Hicks.

${ }^{21}$ Wriothesley, 1:70; on 3 November, Sir John Wallop reported to Lord Lisle that "my lord Thomas dyed in the tower iiij dayes past of an agwe": NA, SP 3/8, fol. $52^{\mathrm{r}}$. After his death, Howard's body was returned to his mother, "so that sche bire him with owte pomp": Ellis, 3:136.

${ }^{22}$ Wriothesley, 1:70.

${ }^{23}$ The servants, Margaret admits, "in ded wer my Lord Thomas sarvands: and the cavse that I tok them for, was ffor the poverty that I saw them in, and ffor no cause els. Bvt seyng, my Lord, that yt ys your plesuer that I shall kepe non that ded be long vnto my Lord Thomas, I wyll put them fro me. And I be seche you not to thynk that eny fancy doth remayn in me towchyng hym; but that all my study and car ys how to plese the Kyngs Grace and to contynv in hys ffaver": Ellis, 3:137. 
conviction. ${ }^{24}$ This perhaps suggests the extent to which the crown found Lord Thomas's actions, however innocently intended, to be a credible threat to its dynastic agenda.

To this end, the official rhetoric of the Howard attainder underscores how his clandestine love endangered the stability of the realm's succession. It begins with a general harangue on the importance of a settled claim: "The hole peace unyte rest and quyetnes of this realme and of the subjects of the same stondeth and dependeth upon the certeynte of the successyon." After rehearsing the importance of the second succession act, a bill passed in the same Parliamentary session, the statute makes clear just how threatening the Howard-Douglas union - an affair that has "lately sythen the begynnyng of this Parliament come to the knowledge of the Kings Highnes" — could have been. Unsurprisingly, the attainder paints Howard's intentions in the worst possible light, and Lord Thomas is tellingly cast as "beyng ledde and seduced by the Devyll not havyng God afore his eyes, [not] regardyng his duetye of Allegeaunce that he oweth to have borne to the Kyng ... [and] suspected and presumed malicyously and trayterously myndyng and imagynyng to putt dyvisyon in this Realme." According to the attainder, the conniving Howard employed "crafyte faier and flateryng Wordes" to orchestrate a match with Douglas, for the sole end that he "shuld aspyre by her to the Dignyte of the sayd Imperyall Crowne of this Realme." Construed thusly, it is a small leap to treason, and Lord Thomas is accordingly condemned to "have and suffer suche paynes and execution of deathe." The statute concludes by generalizing Howard's crime, declaring as treason any subsequent contracting or deflowering of royalty "without the speciall license, assent, consent, and agreament ... of the Kyngz Highnes in wrytyng under his greate seale."25

It is not, however, ultimately clear to what extent King Henry and his ministers intended to punish Lord Thomas specifically. After the immediate threat to Lady Margaret was contained, it is quite possible that Henry seized on an opportunity to continue expanding the purview of his treason legislation, with a universalizing scope that also served as a ready warning for others similarly inclined to meddle with royal blood. In fact, some contemporary accounts saw the entire scandal as little more than a rattling of the royal saber: Reginald Pole, for example, suspected that much of the proceedings were orchestrated to provide Henry with "an opportunity of

${ }^{24}$ In 1531, Richard Roose was attained of treason for murder by poison (Statutes, 22 Hen. VIII, c. 9); in 1541, Queen Catherine Howard was declared a traitor for coming unchaste to the king's bed (Statutes, 33 Hen. VIII, c. 21). In the corresponding statutes, both of the individual crimes were generalized as treason in subsequent English law.

${ }^{25}$ Statutes, 28 Hen. VIII, c. 24. 
showing mercy" on Howard and Douglas, "for their deaths would be so unjust as to create intolerable hatred ... being condemned only on an expost facto law." ${ }^{26}$ Had Lord Thomas not died of illness, perhaps he would have been spared by the king, whose dynastic anxieties were undoubtedly softened by the recent birth of Prince Edward. Whatever the case, one point is certain: Lord Thomas and Lady Margaret played a small, but sordid, role in shaping the vexed political landscape of the mid-1530s. These political affairs had no small resonance in the couple's mutual literary life.

\section{Howard AND Douglas in the Devonshire MS}

The historical drama of Lord Thomas and Lady Margaret finds a complex literary expression in the pages of the Devonshire MS. One of the most important (and vexing) of extant Henrician literary manuscripts, this document is a material witness to the social, collaborative context of literary activity in the early modern court. As mentioned above, it seems to have originated in the household of Anne Boleyn, sometime in the early 1530s; on the basis of internal evidence, the manuscript can be associated with several prominent members of the Howard-Shelton courtly circle, including Mary Shelton, Mary Fitzroy, and, of course, Margaret Douglas. The current binding can be tentatively dated to the early to mid-sixteenth century, so it is likely that the document preserved today in the British Library closely resembles the form in which it was circulated throughout the early modern period. ${ }^{27}$ Members of the queen's circle seem to have entered poems on an ad hoc basis, with little intention of compiling a finite or bounded collection.

Despite the manuscript's undisputed importance, its size and scope have proved a formidable challenge to scholars, who still debate basic features like the identification of its hands. ${ }^{28}$ Matters are complicated further by its relative uniqueness among extant contemporary manuscripts: as one of the only surviving collections of the period devoted exclusively to courtly love lyrics, it is difficult to situate precisely within general composition and

\section{${ }^{26} L \& P, 11: 376$.}

${ }^{27}$ Powell, 3 , notes that "the manuscript was almost certainly tied and wrapped in vellum from the point of its first use." Because of the nature of the binding, accurate collation of the MS has thus far been elusive: see Baron, 325. See also Siemens.

${ }^{28}$ Because space limitations prevent a full bibliographical discussion, this article takes its basic orientation from Baron, whose work provides the most complete available account of the manuscript and its features. For an alternate view, see Remley. 
circulation practices at the Henrician court. ${ }^{29}$ Nonetheless, discrete clusters of related content can be identified within the document, and with proper caution narrative strands can be tentatively extracted from its unruly pages. To this end, the following discussion concentrates on a series of three poetic clusters: discrete groups of lyrics that can be associated with the social and literary interactions of Lord Thomas and Lady Margaret. This article will advance a tentative chronology of how and when these clusters might have found entry into the Devonshire, though this reconstruction will often balance, by necessity, on a shifting foundation of speculation and guesswork. The primary concern, however, is with the poetic texts themselves: this focus will enable a more complete discussion of the Douglas-Howard poems than has been previously offered, by allowing a full account of the textual strategies through which the unhappy lovers attempt to negotiate their tragic fate.

\section{THE HOWARD “PRISON” LYRICS: FOLS. $26^{\mathrm{r}}-30^{\mathrm{r}}$}

If there is a symbolic center of the Devonshire MS, it is Margaret Douglas, whose shaping influence can be detected in a variety of forms throughout the manuscript. She is what Raymond G. Siemens and his colleagues call "the grande dame of the endeavor," having entered sixteen poems in her own hand and acting as "annotator, corrector, and demarcator" for countless more. ${ }^{30}$ On a larger scale, however, Lady Margaret seems to have engaged the manuscript much like its other users did. She explored the expected themes of courtly love in her copywork - including the misogynist postures that typify the discourse - and, as annotator, she bore particular witness to the social context of the Devonshire. ${ }^{31}$ (For example, in one much-discussed piece of marginalia, she and Mary Shelton debate the poetic merits of "Suffryng in sorow in hope to attayn," a lyric ostensibly dedicated to the latter.) ${ }^{32}$ Indeed, Douglas may have even utilized the manuscript to record her budding

${ }^{29}$ On the uniqueness of the manuscript, see Boffey, 7; Marotti, 40; North, 161. Furthermore, because of the manuscript's long active life, it is impossible to speak of a single context for the manuscript: as Powell, 2, describes, "a variety of uses and social environments [is] suggested in the Devonshire."

${ }^{30}$ According to Siemens et al., Douglas can be detected on "at least 50 leaves of the total 114."

${ }^{31}$ See Heale, 1995, 308-09.

${ }^{32}$ British Library Additional MS. 17492, fol. $6^{\mathrm{v}}$ (hereafter cited as D.) For discussion, see Powell, 7. I quote from my own transcriptions of the manuscript. I have compared my readings to those of Dr. Siemens, who kindly shared with me his transcription after this essay was completed. 
relationship with Lord Thomas: on fols. $40^{\mathrm{r}}-44^{\mathrm{r}}$, she enters a series of eight miscellaneous love lyrics, which is immediately followed by several poems suggestively attributed to "T.h." 33 In part, then, Douglas exemplifies larger usage trends in the document, confirming its basic function as a repository of socially mediated literary activity.

Yet, if much of her engagement with the manuscript is conventional, Lady Margaret is also associated with a poetic cluster decidedly atypical of the Devonshire MS as a whole. This sequence, the manuscript's so-called prison lyrics (at fols. $26^{\mathrm{r}}-30^{\mathrm{r}}$ ), seems to have an unmistakable topicality: as will be seen, there is little generic about these poems, which make what must be direct reference to the Douglas-Howard marriage scandal and its fallout. This series of eight poems, entered neatly in the same unidentified hand, has long been the primary site of interest for scholars attempting to situate the Devonshire MS within the sociopolitical intrigue of Lord Thomas and Lady Margaret's forbidden romance. The sequence shares a strikingly common theme - the plight of imprisoned lovers, unjustly torn apart and contains one lyric, "To yowr gentyll letters an answere to resyte," with an internal attribution to "T.h." 34 Given the context of the manuscript, it seems quite likely that these poems were penned by Thomas Howard after his arrest in the summer of 1536.

One can only speculate how these poems found their way into the manuscript. It was not, to be sure, by the pen of Margaret Douglas, whose hand can be established from a holograph letter preserved in the British Library. ${ }^{35}$ Thomas Howard is a far more difficult case. Because no example of Howard's hand has been discovered, we cannot know, for example, if he inscribed the poems personally while imprisoned in the Tower - a suggestion that, given the porous nature of the early modern prison system, is less implausible that it may initially sound, and one that has been entertained by several scholars of the manuscript. ${ }^{36}$ Alternately, it is possible that the poems were collected after Howard's death, and entered by an unknown scribal hand, as tribute and memorial to Lady Margaret's former lover. In lieu of newly discovered evidence, any such assertion must remain tentative. But whatever the provenance of their entry into the manuscript, the central point remains

${ }^{33}$ There is, of course, no way to substantiate that this proximity in the manuscript correlates to any specific social interaction: the positioning could be entirely coincidental.

${ }^{34} D$, fol. $29^{\mathrm{r}}$.

${ }^{35}$ BL Cotton Vespasian F.xiii, art. 188; the document is printed in Ellis, 3:137 (see n23). See also Baron, 324.

${ }^{36}$ See Sherman and Sheils. On Howard's handwriting, see Baron, 326-28; Heale, 1995, 304-05. 
uncontroversial: the poems were almost certainly written by Lord Thomas Howard during the time of his imprisonment, and they bear a remarkable literary witness to the scandal in which he and his precontracted wife were embroiled.

A variety of specific references binds the lyrics contextually to the Douglas-Howard affair, and such circumstantial evidence seems to indicate that Howard himself was their composer. In several places, the speaker refers to his own imprisonment in both literal and figurative terms: in "Now may I morne as one off late," for example, he bewails that "euer pryson stronge / sholde such too louers seperate," while in "What thynge shold cawse me to be sad," he fantasizes that his escape "owt off thys place" shall be "as a hawke that getes owt off hys mue." ${ }^{\text {"37 }}$ Equally telling is his insistent declaration of his faithfulness toward - and, indeed, his directing the lyrics to - a woman cast not simply as his beloved, but as his rightful and lawful wife. In places, the assertion is implicit, as when the speaker vows "I wyll not swerue I yow Insure," a pledge that simultaneously invokes ensure as a verb of general promise and as a verb of betrothal. ${ }^{38}$ Elsewhere, however, he more explicitly voices his desire to be reunited with his wife, with whom he intends " $y n$ godes laws ... to be bownd" forever: indeed, the speaker concludes "Alas that men be so vngent" with a direct address to his "none swete wyfe," the "stay off all [his] lyfe." 39 But most telling is "To yowr gentyll letters," a poem framed (as will be seen in greater detail below) as a verse epistle from a "louyng husband." ${ }^{40}$ Here is the most compelling evidence to suggest that this sequence refers specifically to Lord Thomas and his wife:

for terme off lyfe thys gyft ye haue

Thus now adwe my none swete wyfe

from T.h. wych nowght doth crave

but yow the stay off all my lyfe

This internal ascription to "T.h." confirms that these poems may be reasonably thought to reflect the precise plight of Thomas Howard and Margaret Douglas in the summer of 1536 (fig. 1). This detail, combined with the sequence's general concern with the plight of an imprisoned husband and wife, meets the burden of proof necessary to warrant a biographical reading. Lord Thomas, it seems, wrote these lyrics when imprisoned in the Tower for his clandestine marriage.

\footnotetext{
${ }^{37} D$, fols. $26^{\mathrm{r}}, 27^{\mathrm{r}}$.

${ }^{38}$ Ibid., fol. $26^{\mathrm{r}}$ ("Now may I morne"). See $O E D$, s.v. "ensure, v.," 2, 5 b.

${ }^{39} D$, fols. $26^{\mathrm{v}}$ ("Wyth sorrowful syghes"), $27^{\mathrm{v}}$.

${ }^{40}$ Ibid., fol. $29^{\mathrm{r}}$.
} 


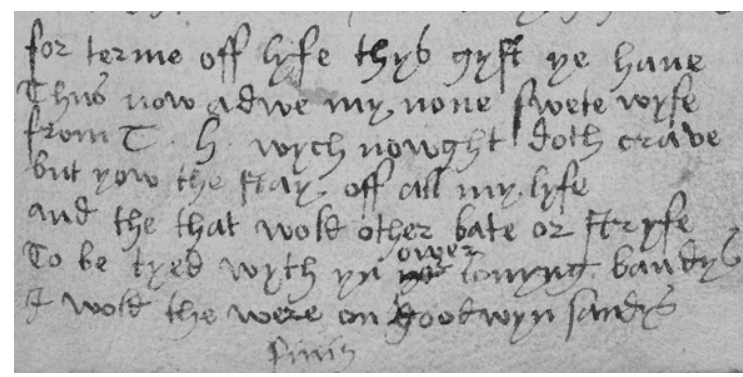

FIGURE 1. BL Additional MS 17492, fol. 29r. Internal “T.h.” attribution. (C) British Library Board.

Though the prison lyrics have long been recognized for their contextual resonance, the poems themselves have received little attention in their own right. This is largely because they have been judged by the canonical standard of Wyatt's verse, the aesthetic touchstone of the manuscript: Muir, for example, summarily dismisses Howard as "not a good poet," and there have been few subsequent attempts to treat his verse seriously. ${ }^{41}$ Yet it seems that, as a unified poetic statement, the lyrics have more to offer than a simple confirmation of the Douglas-Howard scandal, and is worth considering them on their own terms, quite apart from their consistency with the larger corpus of Henrician courtly verse. What follows will attempt to unpack some of the thematic and textual features of the poems in order to elucidate their overall structural unity.

Given the circumstances of their composition, it is not surprising that an atmosphere of terror and claustrophobia is one of the central features of this lyric cluster. Though Howard claims early in the sequence that he "wold yt eschew / to wyte off them that dothe dysdayne / faythfull louers," it proves much harder to evade his captors, whose custody of his physical body is mirrored by their intrusions into his poetic imagination. ${ }^{42}$ Indeed, the presence of what one must assume to be King Henry and his ministers casts a long shadow over the sequence:

The one off us from the other they do absent ${ }^{43}$

***

for let them thynke and let them say

toward yow alone I am full bent ${ }^{44}$

\footnotetext{
${ }^{41}$ Muir, 256.

${ }^{42} D$, fol. $26^{\mathrm{v}}$.

${ }^{43}$ Ibid. ("Wyth sorowful syghes").

${ }^{44}$ Ibid., fol. $27^{\mathrm{r}}$ ("What thyng shold cawse me").
} 
The[y] wyll me hyr for to deny whom I wyll loue moste hartely vntyll I dye ${ }^{45}$

As the poems progress, this unnamed "they" acquires a terrifying potency. This is one of the great aesthetic accomplishments of the poems: combined with Howard's control of tone and mood, such references replicate the atmosphere of paranoia and surveillance, that, it seems certain, was a primary component of the Henrician courtly experience.

Howard does, however, find some means of resistance in the poems that attempt to push back against the great "force" that has "dryuen" him from Douglas. ${ }^{46} \mathrm{He}$ is most vehement in "Alas that men be so vngent," the first half of which entails a bitter indictment of his captors:

Alas that men be so vngent

To order me so creuelly

off ryght they shold them self repent

yff they regard there honesty

They kno my hart ys set so sure

that all ther wordes can not prevayle

Tho that the[y] thynke me to allure

wyth doubyll tonge and flaterynge tayle

alas me thynke the[y] do me wronge

That they wold haue me to resyne

my tytle wych ys good and stronge

that I am yowrs and yow ar myne ${ }^{47}$

Confident in the legal and divine rightness of his "tytle," Howard casts his complaint in decidedly moral terms: the charges latent in digs like "vngent," "creuelly," and "wrong" are counterbalanced by the speaker's appeal that his adversaries "self repent" in the name of "honesty." As the first line's invocation of gentleness implies, at stake here is something like personal honor, and as such, Howard's fierce loyalty to his bride shines in damning contrast to the shamefulness of his captors, whose brutish treatment rends a gentleman from his lawful lady. Quite suggestively, there is also some sense here of how Henry's ministers tried to coerce Lord Thomas in the Tower, though one must wonder what exactly was said "wyth doubyll tonge and flaterynge tayle." In fact, the techniques of his interrogators are further described elsewhere in the sequence: in "Now may I morne," for example, Howard declares that he

\footnotetext{
${ }^{45}$ Ibid., fol. $28^{\mathrm{r}}$ ("Who hath more cawse").

${ }^{46}$ Ibid., fol. $26^{\mathrm{r}}$ ("Now may I morne").

${ }^{47}$ Ibid., fol. $27^{\mathrm{v}}$.
} 
"wyll not swerue . . . for gold nor yet for worldly fere," while in "To yowr gentyll letters," he similarly vows that he will not "be tempte for fere or for gold . . . to refuse or to forsake" his wife. ${ }^{48}$ Despite his captors' bribes, threats, and promises, it seems that Lord Thomas kept his nerve, at least enough to condemn them poetically.

Yet, while some of his poetic energy is directed externally, Lord Thomas seems far more comfortable turning inward, adopting in many poems a kind of stoic consolation anchored in two related notions: the rightness of his cause and the conviction that he and his beloved will be eternally reunited. From the earliest moments of the sequence — as, for example, in "Now may I morne" - Howard boasts that he and Lady Margaret forever "shalbe off one estate," and the trope of indivisibility comes to buttress his relationship to her "whom for ever [his] hart ys plyte [plied]." 49 Yet in the face of their increasingly dire circumstances it also becomes increasingly likely that the restoration of their union will be mediated, not by Henry's earthly authority, but by divine mandate. As such, Howard routinely prays that both he and his beloved will be delivered from their plight:

pray to god to ease owre smart

and shortly togyther that we may goo ${ }^{50}$

***

desyryng god that off hys grace

to send us tyme hys wyll and plesor

and shortly to get hus owt off thys place ${ }^{51}$

***

ffor I do trust ere yt be longe

that god off hys benyngnyte

wyll send us ryght where we haue wrong

for servyng hym thus faythfulye ${ }^{52}$

Though Howard may claim that "nothyng cowld relesse my payne / but to thynke on yow my louer swete," his subsequent poems paint a very different picture: in the face of his unjust torment, he longs for the intervention of a higher power, by whose divine care he and his lover might be reunited eternally. 53

\footnotetext{
${ }^{48}$ Ibid., fols. $26^{\mathrm{r}}, 29^{\mathrm{r}}$.

${ }^{49}$ Ibid., fol. $26^{\mathrm{r}}$.

${ }^{50}$ Ibid., fol. $26^{\mathrm{v}}$ ("Wyth sorowful syghes").

${ }^{51}$ Ibid., fol. $27^{\mathrm{r}}$ ("What thyng shold cawse me").

${ }^{52}$ Ibid., fol. $27^{\mathrm{v}}$ ("Alas that men be so vngent").

${ }^{53}$ Ibid., fol. $26^{\mathrm{r}}$ ("Now may I morne").
} 
Lord Thomas and Lady Margaret do seem to have found some small means to reconstitute their love, even within the confines of the Tower. This can be seen in several poems in the sequence that are cast explicitly as verse epistles between the lovers, including one ostensibly penned by Lady Margaret herself. Read at face value, these poems suggest that during the time of their imprisonment there was some degree of communication between the pair, who seem to have exchanged letters and poems even as the scandal was unfolding. Like so much in the Devonshire MS, it is impossible to reconstruct the precise circumstances that enabled this exchange. One cannot know, for example, if they date from their mutual custody in the Tower, or if they were delivered back and forth from Syon Abbey; similarly, it cannot be determined if they were passed openly or smuggled covertly. ${ }^{54}$ And such inquiries, of course, are themselves grounded on the (itself uncertain) premise that the poems should be taken at their word: it is possible that no such exchange ever occurred, and that the pretense simply provided Lord Thomas with a compelling rhetorical framework for his lyrics. Yet whatever their basis in fact, one point cannot be challenged: the poems, at the very least, implore their reader to think about the possibility of some such exchange, in which Howard and Douglas attempt to shore up their mutual wills against increasing pressure from their captors.

Near the conclusion of the prison lyric sequence, readers of the Devonshire encounter "I may well say with Ioyfull hart," a poem that fast reveals itself to be unlike the others in its company:

I may well say with Ioyfull hart as neuer woman myght say beforn that I haue takyn to my part the faythfullyst louer that ever was born ${ }^{55}$

As the poem unfolds, the female speaker continues in kind, praising the faithful man who "suffereth for my sake / contynnually both nyght and day." Given its context in the sequence, it is likely that readers are meant to understand the poem as emerging from the voice of Lady Margaret, then in custody herself. Though inscribed in the same hand as the rest of the sequence, it is possible that it was actually composed by Douglas, as a token of faith to the spouse who has endured "thretnynges great ... off payne and yke off punnysment" on her behalf. The fiction of the poem, at least, suggests this, though there may even be some further evidence encoded in the language itself. There are several occasions in "I may well say" that seem

\footnotetext{
${ }^{54}$ See Sherman and Sheils.

${ }^{55} \mathrm{D}$, fol. $28^{\mathrm{v}}$.
} 
to deliberately allude to a variety of tropes, images, and phrases used by Howard in earlier poems of the sequence:

My loue truly shall not decay

for thretnyng nor for punysment ${ }^{56}$

Now fayre ye well my none swete wyfe

Trustyng that shortely I shall here

from yow the stay off all my lyfe

and pray to god to ease owre smart and shortly togyther that we may goo ${ }^{60}$ for all the paynes that he doth take from me hys loue wyll not decay Wyth thretnynges great he hath ben sayd off payne and yke of punnysment ${ }^{57}$

And thus fare well my hartes desyer The only stay off me and myne 59

onto god dayly I make my prayer to bryng vs shortly both in one lyne

As the above excerpts suggest, the poem written in the voice of Margaret Douglas is a virtual pastiche of the lyrics presented throughout this prison sequence. It is particularly interesting that none of the borrowings quoted above derive from "Who hath more cawse," the poem directly preceding "I may well say" - accordingly, it is not the case (as, for example, in Spenser's Amoretti 58 and 59) that two adjacent poems are obviously intended to be read in conjunction with each other, as part of an obviously fictionalized exchange. In "Alas that men be so vngent," Howard hopes that he "shortely ... shall here" from his beloved; if he was actively corresponding with Lady Margaret, it seems plausible that he included copies of these lyrics in his missives. ${ }^{62}$ Perhaps Douglas, in return, incorporated his words into her own creation, literalizing the trope of oneness and indivisibility that guides the sequence as a whole.

Lord Thomas may provide a final clue in his next lyric, "To yowr gentyll letters an answere to resyte." As the opening line suggests, this poem casts itself explicitly as an entry in their ongoing correspondence, perhaps in reply to the previous poem in Margaret's voice. In fact, Howard devotes the first stanza to the difficulty of framing his letters in verse:

To yowr gentyll letters an answere to resyte

both I and my penne there to wyll aply

and thowgh that I can not your goodnes aquyte

\footnotetext{
${ }^{56}$ Ibid., fol. $27^{\mathrm{r}}$ ("What thyng shold cawse me").

${ }^{57}$ Ibid., fol. $28^{\mathrm{v}}$ ("I may well say").

${ }^{58}$ Ibid., fol. $27^{\mathrm{v}}$ ("Alas that men be so vngent").

${ }^{59}$ Ibid., fol. $28^{\mathrm{v}}$ ("I may well say").

${ }^{60}$ Ibid., fol. $26^{\mathrm{v}}$ ("Wyth sorowful syghes").

${ }^{61}$ Ibid., fol. $28^{\mathrm{v}}$ ("I may well say").

${ }^{62}$ Ibid., fol. $27^{\mathrm{v}}$.
} 
In ryme and myter elegantly yet do I meane as faythfully As euer dyd louer for hys part

I take god to record whych knowyth my hart ${ }^{63}$

Perhaps the most contextually specific of the sequence, this entry binds the lyrics nakedly to the Douglas-Howard ordeal: Howard here explicitly acknowledges the precise nature of their mutual infraction, noting that their love required Margaret to dismiss her royal blood and "desende from [her] degre." As seen above, this lyric is also the most revealing of the sequence: it is here that the speaker declares himself a "louyng husband," and it is here that he reveals (at least to the reader) his identity as "T.h."

It is, of course, ultimately impossible to know if the lyrics in the Devonshire form the archive of a real correspondence - that is, whether "I may well say with Ioyfull hart" was actually composed by Lady Margaret, in response to her husband's poetic missives, or is merely a poetic fantasy in which the imprisoned Howard attempts to conjure the voice of his grieving spouse. Both explanations are plausible. The Earl of Surrey, for example, would famously compose lyrics in the voice of a woman: in both "O happy dames" and "Good ladies, you that have," Surrey adopts a feminine persona to ventriloquize the grief his wife was ostensibly experiencing for him during his military deployments in the 1540s. ${ }^{64}$ (Curiously, "O happy dames" is the only lyric of Surrey's to be copied into the Devonshire; it is entered by his sister Mary Fitzroy on fol. $55^{\mathrm{r}-\mathrm{v}}$.) Yet all evidence suggests that Margaret Douglas was a capable poet herself, and it is entirely possible that she did compose the lyric, which was then subsequently transmitted to the imprisoned Howard and eventually copied into the manuscript. Whatever the case, the sequence invites its readers to view the lyrics in this manner, as excerpts from the imprisoned lovers' touching correspondence. One may imagine that the idea of such an exchange - a pledge of epistolary solidarity in the face of the direst circumstances - must have provided no small comfort to the imprisoned Lord Thomas, even if he manufactured it entirely himself.

${ }^{63}$ Ibid., fol. $29^{\mathrm{r}}$.

${ }^{64}$ Such acts of ventriloquism may have been informed by larger cultural practices: the work of Marjorie Curry Woods, for example, recovers the longstanding pedagogical tradition, thriving in the classrooms of the early modern period, whereby schoolboys composed exercises in the voice of distressed classical heroines: see Woods, 2001, 2002, and 2009. Woods importantly qualifies, however, that such classroom practices did not necessarily (or even usually) seem to result in the development of empathy for women. 


\section{Medieval Borrowing: Fols. $29^{\mathrm{v}}-30^{\mathrm{r}}, 89^{\mathrm{v}}-92^{\mathrm{r}}$}

After this provocative epistolary exchange, the last entry in the prison lyric sequence is markedly different from those that precede it. Though similar in tone to the other entries, and definitely inscribed by the same hand, the final poem is not an original composition: it is instead a pastiche of stanzas, with minor alterations, from Chaucer's Troilus and Criseyde. ${ }^{65}$ This entry demonstrates another aspect of Howard's literary sensibility: in addition to his own poetic creations, Lord Thomas routinely engaged, here and elsewhere in the manuscript, the medieval poetic tradition to find expression for his grief. This section will examine these poetic borrowings in greater detail to elucidate Howard's complex and varied interactions with this rich source material.

The stanzas from Troilus and Criseyde provide a remarkable culmination to the prison-lyric sequence. As Richard C. Harrier first demonstrated, the initial copyist - the most likely candidate remains Thomas Howard almost certainly utilized as source text William Thynne's 1532 edition of Chaucer, a landmark volume that played an even larger role in the composition of the Devonshire MS. ${ }^{66}$ As a tale of secret love wrenched apart by geopolitical machinations, Troilus and Criseyde has some obvious similarity to the real-life romance of Thomas Howard and Margaret Douglas, and it is not surprising that Lord Thomas found in Chaucer a complaint rhetoric — and, indeed, a rhetorical situation more generally remarkably apt for the events of his own life. Yet Lord Thomas was far from a slavish copyist, and the precise shape of his borrowings suggests the care and attention with which he must have read Thynne's Chaucer.

The four-stanza poem begins with a prefatory couplet, set off at the top of the page: "And now my pen alas / wyth wyche I wryte // quaketh for drede / off that I muste endyte." ${ }^{27}$ This induction originates in the prologue to book 4 of Troilus and Criseyde, the same book from which the rest of the pastiche-poem is derived. In the Chaucerian original, the lines conclude a meditation on the whims of fortune's wheel — the governing motif of book 4, and an archtheme of Troilus and Criseyde more generally - enacting the narrator's somber, yet conventional, discomfort at his tale's upcoming turn, and at the miseries that will befall its actors. Indeed, these lines in the

${ }^{65}$ The source of this particular poem was first recognized by Seaton.

${ }^{66}$ See Harrier.

${ }^{67}$ The virgules here and in subsequent excerpts from the Devonshire MS are present in both the Devonshire and in Thynne's edition of Chaucer; the copyist follows Thynne's text in including them. (Here the double virgule indicates a line break, not a stanza break.) 
Devonshire have been routinely dismissed as perfunctory: Seaton, for example, reduces them to a "commonplace sentiment" clothed in "an uninspired couplet." ${ }^{\text {"68 }}$ Yet however commonplace the couplet, its function in the poem is far more suggestive than it initially appears, especially when one considers its appearance within the larger sociopolitical context of the Devonshire MS. Most basically, of course, it suggests that Howard had some larger familiarity with the shape of Chaucer's tale. By prefacing his excerpt of book 4 with its proem - and thus mirroring, in his selection, the structural integrity of Chaucer's larger whole - he seems insistent on suggesting that his localized pastiche should, and perhaps must, be read within the larger context of Troilus and Criseyde. The lament, it follows, assumes the contextual weight of its Chaucerian origins, and what could have otherwise been seen in the context of a miscellany as an undifferentiated complaint is, to the savvy reader, instead infused with the symbolic freight of Troilus and his plight.

But after this associative network is activated - that is, after Lord Thomas adopts the mantle of Troilus, and implicitly aligns their respective fates - the couplet itself becomes pregnant with a variety of suggestive contextual meanings. Most notable is the significance of endyte, the (reluctant) charge of the Chaucerian narrator. In early modern English, the word indite has a range of possible usages: its primary meanings, which both emerged at the time of Chaucer, encompass both to "utter, suggest, or inspire a form of words which is to be repeated or written down" and to "put into written words, write, pen (a letter, etc.); to inscribe, set down, or enter in writing." ${ }^{69}$ Accordingly, endyte is flexible enough to entail both the act of composition and the act of transcription - and in the context of a miscellany like the Devonshire MS, where the panoply of poetic creation, replication, extraction, and alteration confounds modern notions of authorship, this range of meanings is activated in tandem, the word energized by the material circumstance of its appearance. Expressing his lament in borrowed robes, Thomas Howard here both does and does not endyte, a lexical slippage that mirrors the slippage of personas, in which Howard the poet assumes the voice of Chaucer, just as Howard the lover assumes the voice of Troilus.

Yet, given its proximity to the Douglas-Howard story, the word endyte here also adopts another sense entirely. Within the poetic fiction of the

\footnotetext{
${ }^{68}$ Seaton. Ibid., however, missed the origin of these lines, and thought they were an original composition of the compiler: Southall, 1964, first identified their origin.

${ }^{69} O E D$, s.v. "indite (v.)"; sense 1; 4. A middle usage straddles the two cited above: "To put into words, compose (a poem, tale, speech, etc.); to give a literary or rhetorical form to (words, an address); to express or describe in a literary composition."
} 
Devonshire pastiche, the opening couplet is fused into the lament itself; it is not voiced, as in Chaucer, by a distant narrator, but instead is posed as an utterance of Lord Thomas. When emerging from the pen of the jilted lover, endyte subsequently slides into its morphological cousin indict, a contextual meaning with far less immediate warrant in the Chaucerian original. ${ }^{70}$ In early modern usage, indite and indict commonly intersect, a legacy of their ultimate origins in the root word in + dictare (L. to declare, write down, etc.); a late fifteenth-century Latin grammar, for example, contains entries for both "Indyte letters" and "Indyte for trespas," while an Elizabethan dictionary similarly records both "to sue and indite" and to "indite or pronounce . . . to write."71 When in the voice of Thomas Howard, the man currently imprisoned for a perfectly legal, though politically foolhardy, marriage, it is hard to imagine that the couplet doesn't entail this sense of accusation, a charge against the captors who tore him from his rightful wife. Howard's poetry routinely rails against an unnamed "they," the persecutors of love who lurk in the margins of his prison poems: here, in the final entry of the sequence, Howard employs Chaucer's couplet, radically expanded by context, to make his most naked protestation yet. It is thus no small wonder why his pen "quaketh for drede": the poem - indeed, the entire sequence with which it culminates - is a de facto indictment of King Henry and his ministers, a writ recorded for posterity in the Devonshire.

After this introductory couplet, the poem reproduces (in slightly amended form) four of the six stanzas originally contained in 11. 288-329 of book 4 of Troilus and Criseyde. The preserved material forms a general lament against fortune, the scourge of lovers, and a prophecy of the poet's lonely demise; the two excised stanzas (11. 309-22) are those that most specifically address Criseyde, and thus are of least use to Howard's appropriative aims. Accordingly, the process of selection and excision entails an interpretive balancing act for Howard: the lines preserved must contain enough Chaucerian resonance to establish the allusion to Troilus, yet be flexible enough to mold to the contours of this new contextual frame. The material consequence of this process may be detected in the manuscript, on the two occasions, in stanzas one and three, when Howard elects not to copy Criseyde's name, leaving only a blank gap to signal the omission of Chaucer's heroine (fig. 2). This consequence is a striking visual reminder

${ }^{70} O E D$, s.v. "indict" (I): "To bring a charge against; to accuse (a person) for (of) a crime, as (for) a culprit, esp. by legal process."

${ }^{71}$ The OED entry notes that indite is the "same word orig. as INDICT." (An indictment, of course, is a legal ruling that is proclaimed and subsequently written down.) See Galfridus, fol. i.iii; Thomas, fol. G.g.v ${ }^{v}$, S.ij ${ }^{v}$. 

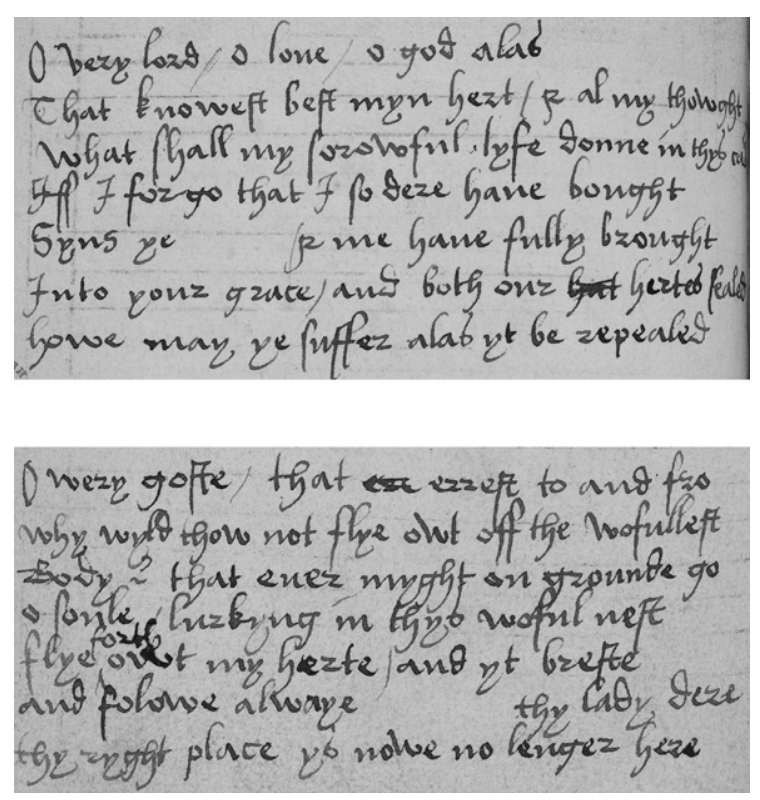

FIGURE 2. BL Additional MS 17492, fol. 29v. Omission of "Criseyde.” (c) British Library Board.

of how readily the copied verse could be appropriated to the plight of another set of lovers: it is easy to imagine Lord Thomas, perhaps when reading, silently inserting the name Margaret into the stanza's empty space. Visually, the omission stands as an act of symbolic defiance, in which Lord Thomas, whose body belonged increasingly to the crown, chose actively to inscribe his wife's name, not into the pages of the manuscript, but into the book of his heart.

To be sure, Lord Thomas had no monopoly on Troilus. As Seth Lerer has argued, Troilus and Criseyde, and the subject positions it explores, had a vibrant symbolic life in the Henrician court, and even King Henry himself seems to have adopted a Troilus persona in love letters to his would-be mistress Anne Boleyn. ${ }^{72}$ Nonetheless, it would be difficult to find a more fitting parallel for Chaucer's tragic lovers than Howard and Douglas, whose private love was overwhelmed by the intervention of quite unsympathetic political forces. Of course, the association itself was not without its

\footnotetext{
${ }^{72}$ See Lerer, 89. Ibid. pushes the notion of Chaucerian applicability to its furthest reaches, arguing that Troilus and Criseyde is a kind of master text for understanding the Henrician courtly experience.
} 
complications: it is difficult to tell, for instance, how Lord Thomas prevented the idealized image of Lady Margaret from being contaminated by the reader's knowledge of Criseyde's ultimate betrayal — or if he even did at all. Though Howard was cut down by the illicit affair, his wife went on to enjoy a long life, ripe with many more lovers and many more scandals. Perhaps, for subsequent readers of the manuscript, Lord Thomas's analogy was finally seen as more fitting than he ever would have wanted.

This touching, and slightly troubling, pastiche, which concludes the socalled Douglas-Howard prison sequence, is perhaps Lord Thomas's most imaginative engagement with a medieval source text, but it is far from his only one. In fact, the final sequence of poems in the Devonshire MS, fols. $89^{\mathrm{v}}-92^{\mathrm{r}}$, is a series of thirteen stanzas excerpted from Chaucerian and pseudo-Chaucerian texts, entered in the same hand that inscribed the sequence of prison lyrics discussed above. Each of the poems represented was printed in Thynne's 1532 edition of Chaucer - including, in addition to more of Troilus and Criseyde, material from Thomas Hoccleve's Letter of Cupid (1402) and Richard Roos's La Belle Dame Sans Mercy (ca. 1450) — so it is almost certain that the copyist had access to the same volume from which the final prison lyric is excerpted. ${ }^{73}$ But even more suggestively, this sequence is the only place in the manuscript with a series of poems written in the same hand that inscribed the Howard prison lyrics. ${ }^{74}$ Though the evidence is indeed circumstantial, it seems entirely probable, given the lack of other candidates, that Thomas Howard was the guiding hand of these excerpts.

Here again Lord Thomas turns to Chaucer for the language of love: these are stanzas, with only minor exception, devoted to the trials and tribulations of the amatory arts. Though it lacks the concentrated unity of the prison lyrics, there is indeed something similarly dialogic in this selection. Lerer, for example, argues that these excerpts enact "a miniature epistolary exchange, a set of alternating male- and female-voiced stanzas" that, in the medieval tradition of amatory contests, debate the cruelty and constancy of the courtly mistress. ${ }^{75}$ Yet while there is a polyvocal aspect of the selection, there may be less controversy here than Lerer suggests: in fact,

\footnotetext{
${ }^{73} \mathrm{Or}$, at least, access to some manuscript that had originally been copied from Thynne. Again, it is possible that this material was available even in the Tower.

${ }^{74} \mathrm{The}$ hand has been located in three other places in the manuscript: it emends a single line of "To cause accorde" at $D$, fol. $69^{\mathrm{r}}$, encodes a two-line riddle at fol. $67^{\mathrm{r}}$, and, most suggestively, records a single stanza of Chaucer (Troilus, 11. 946-52; fol. c.lxxv ${ }^{\mathrm{v}}$ in Thynne's edition) at $59^{\mathrm{v}}$. See Baron, 332 .

${ }^{75}$ For Lerer, 151-52, the opening lines of the sequence - "Womans harte vnto no crewelyte / enclynyd ys" - thus serve as "the topic for discussion, the resolution, as it were, for the debate."
} 
of the thirteen stanzas copied in this section, only two unambiguously embrace anything like an oppositional stance. ${ }^{76}$ Indeed, the excerpts copied in this final section of the manuscript are notable for the relative consistency of their outlook: whatever the context of their original source, the lines excerpted in the Devonshire MS almost inevitably read as miniature volleys in the medieval defense-of-women tradition. ${ }^{77}$

As seen above, and as Elizabeth Heale has documented more fully, one senses a degree of gender play in much of the Devonshire lyrics: malevoiced verse is copied and composed by women, female-voiced verse is copied and composed by men, misogynist lyrics are copied and responded to by women, and so on. Still, this section of the manuscript is unusual in the concentration of its theme, and it seems clear that Howard actively sought to preserve a collection of verse that primarily extolled the virtue of women. The first entry, an excerpt from Hoccleve, sets the tone for much of the rest:

Womans harte vnto no crewelyte enclynyd ys / but they be charytable pytuous deuoute ful off humylyte shamefast debonayre / and amyable dredeful / and off wordes measurable what women these haue not parauenture folowyth not the way off her nature ${ }^{78}$

Though the precise expression perhaps leaves something to be desired, one can at least credit Howard with good intentions: he seems interested, in the section that follows, to combat the conventional misogyny that is present in much of the Devonshire MS. Many of the lyrics in this section are different permutations of the same basic theme, the mistreatment of women in life and love. Some, for example, such as "for thowgh I had yow to morow agayne" and "Also wyckyd tonges byn so prest," lament in a woman's voice, while others, such as "how frendly was medea to Iason" entail fairly pat, epigrammatic statements on the treachery of men. ${ }^{79}$ Lord Thomas is fast committed to this agenda, at least in his medieval borrowings: with only

${ }^{76}$ The two in question are "yff yt be so that ye so crewel be" and "wo worthe the fayre gemme vertulesse," a pair of consecutive stanzas from Troilus and Criseyde (book 1, 11. 337-51; fol. c.lxxviiiv in Thynne's edition).

${ }^{77}$ Heale, 1995, 306, notes that these stanzas "utter with an unusual forcefulness a woman's view of the dangers and doubleness of male rhetoric."

${ }^{78} \mathrm{D}$, fol. $89^{\mathrm{v}}$.

${ }^{79}$ Ibid., fol. $91^{\mathrm{r}}, 91^{\mathrm{v}}, 91^{\mathrm{r}}$. 
minor exceptions, all of the stanzas in this sequence are marshaled to this general end.

In fact, Howard actively emended his excerpts to suit this thematic need - as, for example, in the short stanza "yff all the erthe were parchment scrybable," an excerpt from the pseudo-Chaucerian The Remedy of Love. ${ }^{80}$ Thynne prints the stanza as following:

If al the erthe were parchement scribable

Spedy for the hande / and al maner wode

Were hewed and proporcioned to pennes able

Al water ynke / in damme or in flode

Euery man beyng a parfyte scribe $\&$ good

The cursydnesse yet and disceyte of women

Coude not be shewed by the meane of penne ${ }^{81}$

As a piece of conventional poetic misogyny, the lines are fairly unremarkable. Yet Lord Thomas seems to recognize that the center of gravity in this passage is not misogynist discourse, but rather the continuing amplification of the writing metaphor - and as such, he realizes that only a small intervention can subvert its meaning entirely. When copying the stanza, Howard upends his source by simply exchanging two words in its penultimate line: in the Devonshire iteration, what "cowde not be shewyd by the meane off penne" is not feminine treachery, but rather "the faythfulnes yet and prayse of women." This example is quite suggestive about Howard's engagement with Thynne's 1532 edition: if it was indeed he who first located the source stanza, he clearly read with enough active interest to imagine the radical altering of textual meaning.

Unlike the prison lyrics, which insistently rely on contextual cues to invoke a precise biographical moment, there is little that grids the medieval sequence to a particular episode of Lord Thomas's life. And while this doesn't disqualify them from having a direct connection to Howard's disgrace and imprisonment, it must be admitted that such claims cannot be substantiated. Yet at the same time, the identical handwriting and the usage of Thynne's 1532 Chaucer suggest that the two sequences could emerge from the same period of inscription; one could then speculate that perhaps these excerpts were also entered by Howard during his imprisonment. This biographical context might, for example, help account for the few thematic outliers in the medieval sequence, such as the excerpt "O marble herte":

\footnotetext{
${ }^{80}$ Ibid., fol. $90^{\mathrm{r}}$.

${ }^{81}$ Chaucer, fol. ccc.lxvi ${ }^{\mathrm{v}}$.
} 
O marble herte / and yet more harde perde wyth mercy may not perce for no labor more stronge to bowe than ys a myghty tree what avayleth yow to shewe so great rygor pleasyth yt yow more to se me dye thys hourt before yowr eyen for yowr dysporte and play than for to shewe some comforte and socour to respyte death / wych chaseth me alway ${ }^{82}$

In La Belle Dame Sans Mercy, the speaker of these lines deploys the familiar tropes of courtly love: if the beloved does not show him the mercy of her favor, he will surely die from her cruelty. Yet it is interesting to note that, in the context of the Devonshire, the lines themselves contain no explicit mention of love, and nothing anchors the participants to any particular voice or gender identity. It seems that this passage, severed from its original context - and in the hands of a poet-compiler who can radically alter the meaning of his source texts - can also entail a more literal plea for mercy, in search of "some comforte and socour / to respyte" a more literal death. When mediated through Thomas Howard, perhaps these lines were directed not to a cruel lover, but to a cruel king, whose notorious heart could be "more stronge to bowe than ys a myghty tree."

There is a similar ambiguity in the stanza that follows, another excerpt from La Belle Dame Sans Mercy:

Alas what shuld yt be to yow preiudyce yff that a man do loue yow faythfully to yowr worshyp eschewyng euery vyce so am I yowrs and wylbe ueryly I chalenge nowght of right / and reason why for I am hole submyt vnto yowr servyce right as ye lyst yt be right so wyll I to bynd myself w[h]ere I was at lyberty ${ }^{83}$

In the medieval source, this passage is a profession of male constancy designed to thaw the heart of the poem's indifferent mistress - and given the amatory context of the original, it is certainly possible that the Devonshire copyist was charmed by this vow of erotic fealty. Yet it is also worth noting that, as in "O marble herte," there is little here that strictly necessitates an eroticized reading of the stanza in isolation. In fact, if one reads the pledge of allegiance literally — that is, if one temporarily

\footnotetext{
${ }^{82} D$, fol. $90^{\mathrm{r}}$.

${ }^{83}$ Ibid.
} 
disassociates the language of service from its figurative, eroticized form the lines sound equally as a profession of political loyalty. Words such as faythfully, worshyp, submyt, servyce, and bynd suggest the availability of an alternate discourse, one apt, not for the wooing of a mistress, but for the wooing of a king. Such lines may well have been poignant for the disgraced Thomas Howard on multiple registers, especially, it seems, the final turn, by which the speaker ironically discards his "lyberty" for the pleasures of willing service. If these lines were excerpted by Howard during his imprisonment in the Tower, one might wonder about their intended audience, to whom Lord Thomas professes his loyalty.

If a biographical context for this section could be substantiated, one might indeed read "O marble herte" and "Alas what shuld yt be" as figurative missives to King Henry, just as one might assume that Howard's turn to antimisogynist poetics was prompted by Lady Margaret's exposure and arrest. And yet while one cannot situate the medieval sequence thus precisely, the very possibility of such readings is telling, and suggests something more generally about how the Chaucerian stanzas contribute to Howard's persona as a poet-compiler in the manuscript. Given his own place in the Henrician court, it is of no small significance that Lord Thomas felt compelled to mount such an extensive and concentrated defense of women - and even more so, that he did so by borrowing the voice of Chaucer. As Greg Walker has elegantly argued, Chaucer's legacy was a site of intense ideological contestation in the 1530s, in which the premier poet of England's past was variously deployed in service of the nation's future. Thynne's landmark edition, it follows, is but the most notable example of how contemporary engagement with Chaucer responded to the social upheavals that characterized the king's ongoing break with Rome. ${ }^{84}$ But, as anticipated by Howard's reworking of Troilus in the prison lyrics, Chaucer was an equally apt vehicle for exploring — and, indeed, exposing - the intersection of gender and power in the contemporary courtly sphere: it was this possibility that Lord Thomas may have sought to seize upon in his series of medieval excerpts.

In her perceptive reading of the sequence, Elizabeth Heale notes that it "would be pleasant to be able to claim that these stanzas were copied by a woman, sifting through the 1532 Chaucer for language with which to

\footnotetext{
${ }^{84}$ For Walker, 56, the paratextual and editorial features of Thynne's volume entail "a subtly coded call for religious stability and consensus, part of that concerted attempt by members of the conservative scholarly and literary establishment at court and in London to draw Henry VIII back from the brink of religious and political revolution, and restore a sense of equilibrium to domestic politics and political culture." See also Watkins.
} 
enunciate a woman's experience of courtly love," but she immediately acknowledges that it is also "entirely possible that they were noted and copied out by Lord Thomas Howard or by another man." ${ }^{\prime \prime 5}$ Indeed, other scholars have sought to link these stanzas, and others in the manuscript, to the pen of a woman, ostensibly to locate such protofeminist sentiments within an identifiable subject - or perhaps a kind of subject - at King Henry's court. ${ }^{86}$ And while this kind of recovery is certainly desirable, it is crucial to note that the candidacy of Lord Thomas - better-substantiated by the available evidence, as slight as it is - can offer an alternate, but no less compelling, account of Henrician gender politics. In fact, there is a way in which Howard can be seen as a largely feminized figure in the Devonshire MS, something of a reflection, perhaps, of his larger place in the court politics of the mid-1530s. Other than Henry Stuart - Margaret Douglas's son, who inscribed a single poem in the final phase of the manuscript's active life - Lord Thomas is the only man whose name we can link to a probable hand in the Devonshire. As such, Howard's presence in the manuscript resembles not the likes of Wyatt, Edmund Knivet, and Anthony Lee - men to whom poems are attributed, but who clearly did not inscribe them personally - but is much closer to court ladies like his wife Margaret Douglas, Mary Shelton, and Mary Fitzroy - women who seem to have actively contributed to the manuscript qua material object.

Given the hyper-virile context of Henrician politics, it is tempting to wonder to what extent Lord Thomas felt — or, perhaps more rightly, was made to feel — like something of an impotent figure. Thomas, it seems, was by far the least accomplished of his Howard kinsmen, and it is hard to imagine how he contended with the loss of Margaret, from whom he was so easily removed by the whim of a king. It is possible that Lord Howard identified with the courtly women with whom he was, and remains today, so closely associated. Because of his disastrous misstep, Lord Thomas may have been subject to many of the forces and constraints that one would more immediately associate with women of the period, namely, the complete effacement of individual erotic agency for the sake of interests deemed more necessary by the culture's logic. This is, of course, the social equation that led to the downfall of his wife, and it is the social equation responsible for the ruin of Queens Anne Boleyn and Catherine Howard (both, incidentally, nieces to Lord Thomas). If Howard indeed was, within the rules of his own culture, what one might called emasculated, perhaps he felt some special

\footnotetext{
${ }^{85}$ Heale, 1995, 307. On the role of women in manuscript compilation more generally, see Heale, 2004; Clarke; Burke.

${ }^{86}$ See Remley; more generally, see Goldberg.
} 
affinity with the plight of his female kin, and, perhaps, with women more generally. Though certainly speculative, such a reading may account for his forceful defense of women in the Devonshire.

\section{AFTERWORD: HOWARD'S LEGACY}

Though we cannot know when Howard entered the medieval sequence into the Devonshire MS, and we cannot know to what end it was meant to be directed, one thing is clear: his personal participation in the manuscript ended in October 1537, when he succumbed to illness in the Tower. The use of the Devonshire MS continued long after the death of Lord Thomas: as mentioned above, the manuscript seems to have ended up in the possession of Lady Margaret, whose son Henry (not born until 1545) would eventually enter a lyric in his own hand ${ }^{87}$ Based on the scant available evidence - and assuming that current theories about the manuscript indeed hold true - it appears that Margaret virtually stopped entering new poems into the Devonshire after the death of her husband. However, the small activity of hers that can be documented is quite telling, especially her poetic responses to Howard's tragic end.

What may have been Margaret Douglas's last entry in the Devonshire MS is also, perhaps, her most moving. Written in a thick, smudged ink, "now that ye be assemblled heer" seems to be the last original composition in the manuscript, separated by just a blank folio from Thomas Howard's sequence of medieval excerpts. ${ }^{88}$ (This proximity, given the content of the lyric, is also telling.) The assembly of the poem's title is revealed in the opening stanza, which masterfully situates the rhetorical moment:

now that ye be assemblled heer

all ye my ffrynds at my request

specyally you my ffather dere

that off my blud ar the nerest

thys vn to you ys my request

that ye woll pacyenlly hyre

by thys my last words exprest

my testement Intyer

In the fiction of the monologue, Douglas has gathered her social circle including, one may assume, some of the people who wrote in the Devonshire MS - on the occasion of her pending death. The preamble, however,

${ }^{87} \mathrm{D}$, fol. $57^{\mathrm{r}}$ ("My hope is yow for to obtaine").

${ }^{88}$ Ibid., fol. $88^{\mathrm{r}}$. 
obscures the immediate circumstances of the crisis, and it is not precisely clear why Lady Margaret anticipates her end. Her rationale reveals itself gradually in the second stanza:

and thynk nat to Interrupte me

ffor syche wyse provyded hawe I

that thoght ye welld yt woll nat be

thys touer ye se ys strong and hye

and the dooris fast barred hawe I

that no wyhght my purpose let shold

for to be quen off all Italy

nat on day lengere leve I wold

The logic of the stanza - and, indeed, of the poem generally — unfolds gradually, as the revelation of Margaret's intentions retroactively amplifies the already tense dramatic scene. Initially, the force of her protestation the image of the barred tower door, and the boast that "no wyght my purpose let shold" - seems incongruous with her stated purpose: it is not certain why her spectators would "Interrupte" her final declaration. As the stanza concludes, however, it becomes clear that the speaker's will, that is, the precise "yt" that the audience "welld yt woll nat be," entails much more than just her final words: it seems that she intends, at least symbolically in the poem, to take her own life. ${ }^{89}$ Throughout the stanza, the threat of suicide is punctuated by a variety of contextual marks that underscore the precise plight of Margaret's situation: the "touer" of her "fast barred . . . purpose" stands as the obvious inverse to her (and her husband's) autonomy-robbing imprisonment, while the expected proverbial sense of "to be quen off all Italy" is strikingly literalized when one remembers that Lady Margaret was, in fact, a valuable pawn for Henry in the international marriage market. ${ }^{90}$

In the poem's final stanza, the suicide motif is amplified, as the speaker's purpose and motivation are ultimately revealed. It is this stanza that most obviously connects the lyric to Lady Margaret's own saga:

wher ffor swet ffather I you Pray

ber thys my deth with pacyence

and tourment nat your herys gray

but frely pardonn myn offence

\footnotetext{
${ }^{89}$ Hammons, 407, suggests that the suicide trope "subtly serves as an act of resistance by denying Henry VIII's power over her body."

${ }^{90}$ Heale, 1995, 309n32, observes that "tower ... strong and hye" seems to echo Surrey's "In towre both strong and highe" — a phrase, as noted above, that almost certainly refers to the imprisonment of Lord Thomas.
} 
sythe yt presedeth off lowes fferuence and off my harts constancy let me nat ffrom the sweeat presence of hym that I haw caseyt to dy

Though concerned with consoling her father, whose presence in the poem underscores Margaret's premature, unnatural death, she equally invokes the laws of love - "fferuence" and "constancy" - to beg indulgence for her coming "offence." Of course, her apology is multifaceted: while it looks forward to the suicide, it equally looks back to that which prompts the lyric itself, her role in the death of Lord Thomas. Borrowing a trope from the Howard prison sequence, Douglas imagines that her own death will return her to her lover's "sweeat presence," a pledge designed to make some amends for the ruin she has inadvertently brought upon them both.

Of course, this reading of the poem relies heavily on a close contextual linkage to Margaret Douglas's private tragedy. And there is, it must be said, no external evidence that conclusively links the poem to the Thomas Howard affair: though it was copied in Margaret's hand, the work is impossible to date, and there is no way to be fully sure that she composed it herself. Furthermore, a skeptic could easily dismiss the post-Romantic folly of assuming that the voice of the poem's speaker is identical to the voice of Lady Margaret: it is, after all, merely a lyric poem. Yet despite these reasonable cautions, the circumstantial evidence is compelling: it is hard to imagine that this precise lyric could be copied by Margaret Douglas without some contextual association with the tragic events of her short first marriage. It is quite likely that Douglas entered the poem into the Devonshire sometime after Lord Thomas's death in October 1537 - though how long after remains unknown - during a time of mourning (or perhaps remembrance) for her late husband. To this end, the lyric's position in the manuscript is telling: as noted above, it appears almost immediately (fol. $88^{\mathrm{r}}$ ) before the sequence of medieval excerpts (fols. $89^{\mathrm{v}}-92^{\mathrm{r}}$ ) associated with Howard's hand. It is possible that Lady Margaret, in the midst of her mourning, returned to the pages of the manuscript that concretely bore the mark of her lost lover. It is quite reasonable that she may have entered her own lament in this adjacent leaf, thus inscribing in the manuscript a material warrant for the trope of proximity and indivisibility so often deployed in their mutual poems.

There is a final piece of circumstantial evidence, located elsewhere in the Devonshire, that may help substantiate this claim. Again, one must turn to the manuscript first as a physical object, via the material condition of the early poem "what nedythe lyff when I requyer," a lyric in the midst of the generic 
sequence that may have emerged from the Douglas-Howard courtship. ${ }^{91}$ Entered, and possibly composed, by Lady Margaret, the lyric is a relatively undifferentiated lament for lost love: despite the apparently clear refrain that "another hathe that ons was myne," the poem does little to specify the precise circumstances of the occasion, and it is not clear if it emerges from a male or female voice. Given its relative position in the document, the lyric can be tentatively dated to the manuscript's early days in the Boleyn household, possibly during the initial courtship of Lady Margaret and Lord Thomas. Or at least most of it can - for at some later date, Margaret seems to have returned to the lyric to append an additional stanza:

what hart cowld thynk mor then was thoght

or tong cowld spek mor then was spok

yet what ffor that all was ffor noght

ffor he ys gone and slept the knot

wharby I se beffor my yen

a nother haws that ons was myn ${ }^{92}$

These lines, which are admittedly quite obscure, seem to attribute the poem to a female speaker. But even more interestingly, the lines appear to be inscribed by the same pen and the same ink with which Margaret wrote "now that ye be assembeled heer" (figs. 3 and 4). Though it is virtually impossible to definitively match the samples, a visual inspection is telling: in no other place in the manuscript does Douglas write her poems or annotations in such thick, smudged ink. By all appearances, the stanza added to "what nedythe lyff when I requyer" was appended in the same session that Lady Margaret entered the suicidal mediation on her husband's death. Though the new lines seem relatively consistent with the content of the earlier poem, the lament might also sound a very different note if they were added by Douglas after Lord Thomas's death. "[A]ll was ffor noght / ffor he ys gone" could contain an embedded reference to her lost husband.

Beneath the new concluding stanza of "what nedythe lyff," Margaret added an epigram in the same dulled pen:

and thys be thys ye may

asuer your selff off me

no thyng shall make me to deney

that I hawe promest the[e]

${ }^{91} D$, fol. $43^{\mathrm{v}}-44^{\mathrm{r}}$.

${ }^{92}$ See Heale, 1995, 308. The quill in which the last stanza is written is far more degraded than those that precede it; it seems rather unlikely, if the poem was inscribed in one session, that Douglas would switch to such a dull pen so late in the session. 


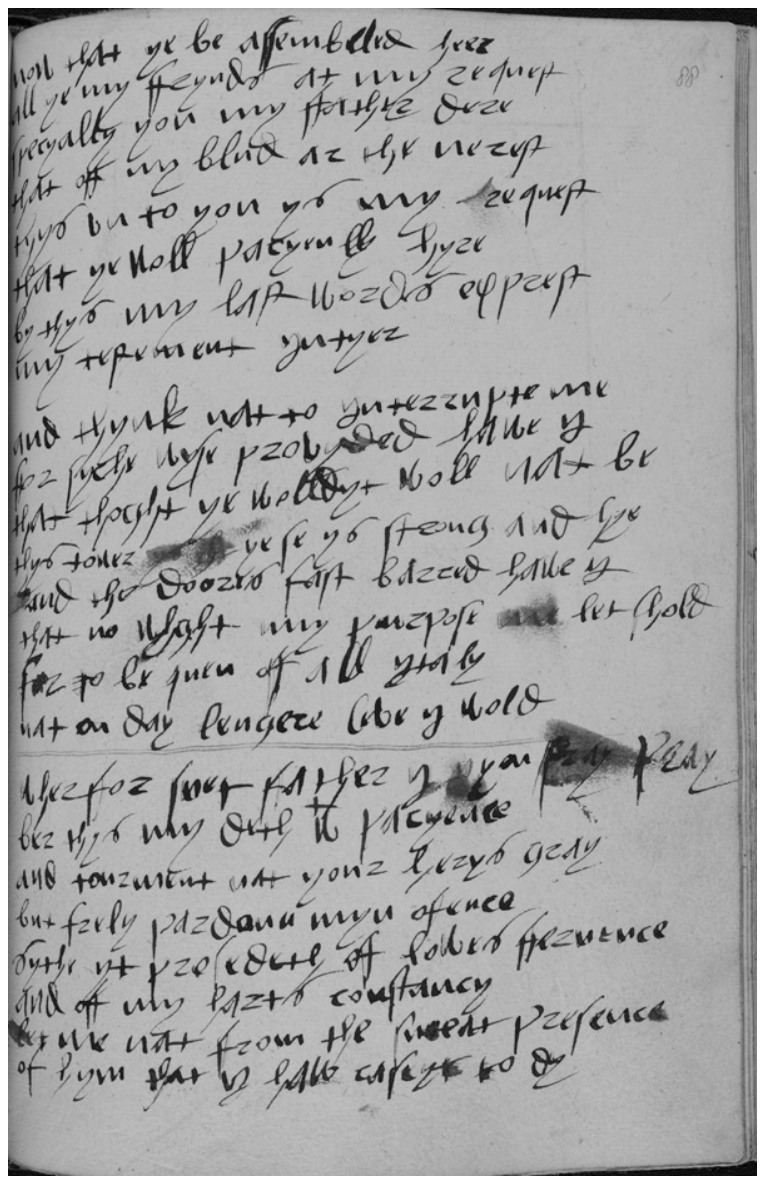

FIGURE 3. BL Additional MS 17492, fol. $88^{\mathrm{r}}$. Excerpt from "Now that ye be assemblled heer.” (C) British Library Board.

After everything seen so far in the manuscript, these lines could be an eternal pledge to Lord Thomas, already dead at the time of its entry. The reality, of course, may be far more pedestrian, but the Devonshire MS invites readers to situate its contents within the Henrician courtly milieu from which the collection emerged. As this essay has tried to show, the remarkable saga of Lord Thomas and Lady Margaret can be tentatively traced through the pages of the Devonshire MS. There are at least three discrete groupings of poems in the manuscript that can be linked to different moments in the DouglasHoward scandal: the Howard prison lyrics, the borrowings and adaptations from the medieval poetic tradition, and those poems that seem to address the aftermath of the scandal. In each of these sections, one can detect the various 


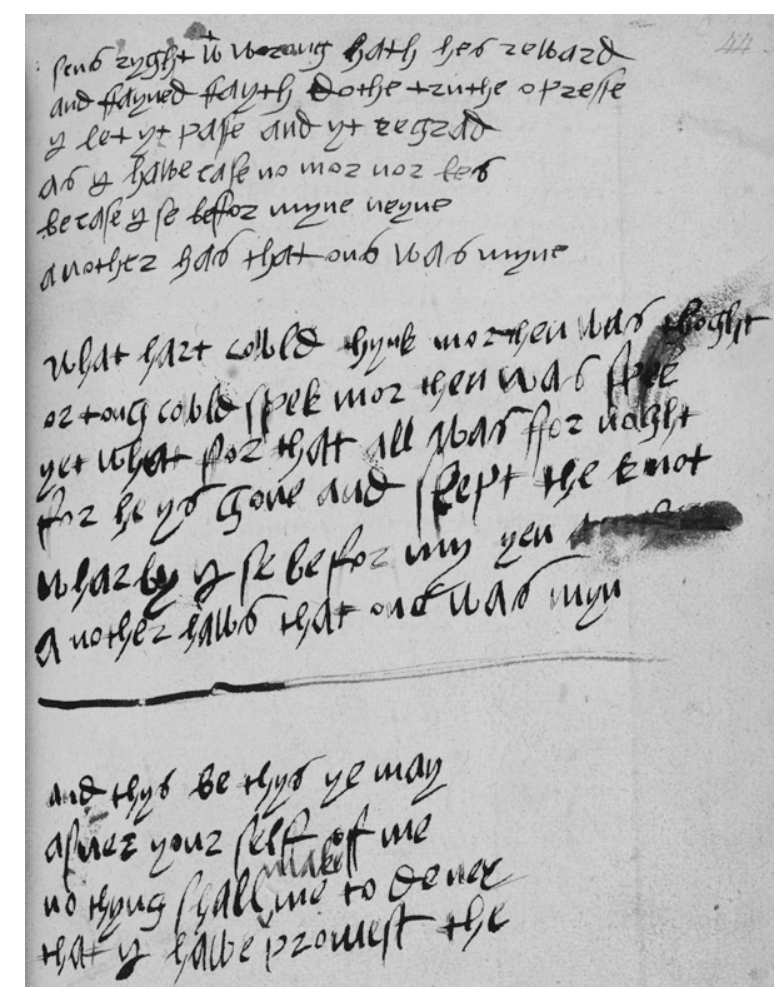

FIGURE 4. BL Additional MS 17492, fol. $44^{\mathrm{r}}$. Stanza appended to "what nedythe lyff when I requyer." (C) British Library Board.

poetic strategies through which either Lord Thomas or Lady Margaret attempted to cope with the remarkable circumstances in which they were ensnared: and one can, by extension, attempt to situate their respective responses within the larger matrix of gender ideology at the Henrician court.

Many of the above claims, of course, have relied on varying degrees of speculation, but, with an emphasis on transparency, they have attempted to model one manner of adopting a responsible critical orientation toward manuscripts like the Devonshire MS. As should be apparent, the DouglasHoward scandal is but one thread running through the Devonshire MS, and there are countless more waiting to be investigated. The groundbreaking work of scholars such as Helen Baron, and the ongoing efforts of Raymond G. Siemens and his colleagues, have and will continue to refine our basic understanding of the manuscript, equipping us with the necessary tools and data to confront it more squarely. We must now see what awaits us inside.

The University of Texas at Austin 


\section{Bibliography}

Baron, Helen. "Mary (Howard) Fitzroy's Hand in the Devonshire Manuscript." The Review of English Studies 45.179 (1994): 318-35.

Boffey, Julia. Manuscripts of English Courtly Love Lyrics in the Later Middle Ages. Suffolk, 1985.

Bond, Edward A. "Wyatt's Poems." Athenaeum 2274 (1871): 654-55.

Burke, Victoria. E. "Manuscript Miscellanies." In The Cambridge Companion to Early Modern Women's Writing, ed. Laura Lunger Knoppers, 54-67. Cambridge, 2009.

Chaucer, Geoffrey. The workes of Geffray Chancer newly printed, with dyuers workes whiche were neuer in print before. Ed. William Thynne. London, 1532.

Clarke, Elizabeth. "Women's Manuscript Miscellanies in Early Modern England." In Teaching Tudor and Stuart Women Writers, ed. Susanne Woods and Margaret P. Hannay, 52-60. New York, 2000.

Ellis, Henry, ed. Original Letters Illustrative of English History. $3^{\text {rd }}$ series. 4 vols. London, 1846.

Galfridus, Anglicus. Incipit liber q[ui] dicitur Promptorium paruulorum siue clericorum. London, 1499.

Goldberg, Jonathan. Desiring Women Writing: Renaissance Examples. Palo Alto, 1997.

Hammons, Pamela S. "The Gendered Imagination of Property in Sixteenthand Seventeenth-Century English Women's Verse." Clio 34.4 (2005): 395-418.

Harrier, Richard C. "A Printed Source for 'The Devonshire Manuscript." The Review of English Studies, n.s., 11.41 (1960): 54.

Head, David M. "Beyng Ledde and Seduced by the Devyll': The Attainder of Lord Thomas Howard and the Tudor Law of Treason." Sixteenth Century Journal 13.4 (1982): 3-16.

Heale, Elizabeth. "Women and the Courtly Love Lyric: The Devonshire MS (BL Additional 17492)." The Modern Language Review 90.2 (1995): 296-313. . '“Desiring Women Writing': Female Voices and Courtly 'Balets' in Some Early Tudor Manuscript Albums." In Early Modern Women's Manuscript Writing: Selected Papers from the Trinity/Trent Colloquium, ed. Victoria E. Burke, Jonathan Gibson, and Elizabeth Clarke, 9-31. Aldershot, 2004.

Hicks, Michael. "Bigod, Sir Francis (1507-1537)." Oxford Dictionary of National Biography. http://www. oxfordddnb.com/view/article/2375 (accessed 10 September 2010).

Journal of the House of Lords, 1509-1577. Vol 1. London, 1802.

Lerer, Seth. Courtly Letters in the Age of Henry VIII: Literary Culture and the Arts of Deceit. Cambridge, 1997.

Letters and Papers, Foreign and Domestic, of the Reign of Henry VIII. Ed. J. S. Brewer et al. 23 vols. London, 1862-1932.

Marotti, Arthur F. Manuscript, Print, and the English Renaissance Lyric. Ithaca, 1995.

Marshall, Rosalind K. "Douglas, Lady Margaret, Countess of Lennox (1515-1578)." Oxford Dictionary of National Biography. http://www. oxfordddnb.com/view/article/7911 (accessed 10 September 2010).

Muir, Kenneth. "Unpublished Poems in the Devonshire MS." Proceedings of the Leeds Philosophical Society 6 (1947): 253-82.

Murphy, Beverley A. Bastard Prince: Henry VIII's Lost Son. Gloucestershire, 2001. 
North, Marcy L. The Anonymous Renaissance: Cultures of Discretion in Tudor-Stuart England. Chicago, 2003.

Powell, Jason. "Marginalia, Authorship and Editing in the Manuscripts of Thomas Wyatt's Verse." English Manuscript Studies, 1100-1700 15 (2009): 1-40.

Remley, Paul G. "Mary Shelton and Her Tudor Literary Milieu." In Rethinking the Henrician Era, ed. Peter C. Herman, 40-77. Urbana, 1994.

Riordan, Michael. "Howard, Lord Thomas (c. 1512-1537)." Oxford Dictionary of National Biography. http://www. oxfordddnb.com/view/article/70793 (accessed 10 September 2010).

Seaton, Ethel. “'The Devonshire Manuscript' and its Medieval Fragments." Review of English Studies, n.s., 7 (1956): 55-56.

Sherman, William H., and William J. Sheils, eds. Prison Writings in Early Modern England. Special issue of Huntington Library Quarterly 72.2 (2009).

Siemens, Raymond G., et al. "Drawing Networks in the Devonshire Manuscript (BL Add 17492): Toward Visualizing a Writing Community's Shared Apprenticeship, Social Valuation, and Self-Validation." Digital Studies 1.1 (2009), http://www.digitalstudies.org/ojs/ index.php/digital_studies/article/view/ 146/201 (accessed 1 February 2010).

Southall, Raymond. "The Devonshire Manuscript Collection of Early Tudor Poetry, 1532-41." The Review of English Studies, n.s., 15.58 (1964): 142-50.

- "Mary Fitzroy and 'O Happy Dames' in the Devonshire Manuscript." The Review of English Studies, n.s., 45.179 (1994): 316-17.
State Papers, Henry VIII. 11 vols. London, 1830-52.

Statutes of the Realm. Ed. A. Luders et al. Vol. 3. London, 1810-28.

Surrey, Earl of [Henry Howard]. The Poems of Henry Howard, Earl of Surrey. Ed. Frederick M. Padelford. London, 1966.

Thomas, Thomas. Dictionarium linguae Latinae et Anglicanae. London, 1587.

Walker, Gregg. Writing under Tyranny: English Literature and the Henrician Reformation. Oxford, 2005.

Watkins, John. "Wrastling for this world': Wyatt and the Tudor Canonization of Chaucer." In Refiguring Chaucer in the Renaissance, ed. Theresa M. Krier, 21-39. Gainesville, 1998.

Woods, Marjorie Curry. "Boys Will Be Women: Musings on Classroom Nostalgia and the Chaucerian Audience(s)." In Speaking Images: Essays in Honor of V. A. Kolve, ed. Robert F. Yeager. and Charlotte C. Morse, 143-66. Asheville, 2001.

- "Weeping for Dido: Epilogue on a Premodern Rhetorical Exercise in the Postmodern Classroom." In Latin Grammar and Rhetoric: From Classical Theory to Medieval Practice, ed. Carol Dana Lanham, 284-94. New York, 2002.

. "Rhetoric, Gender, and the Literary Arts: Classical Speeches in the Schoolroom." New Medieval Literature 11 (2009): 113-32.

Wriothesley, Charles. A Chronicle of England During the Reigns of the Tudors, from A.D. 1485 to 1559. Ed. William Douglas Hamilton. 2 vols. London, 1875-77. 